\title{
Gene Expression under Short-Term Low Temperatures: Preliminary Screening Method to Obtain Tolerant Citrus Rootstocks
}

\author{
Amparo Primo-Capella *, Mary-Rus Martínez-Cuenca (D) and Maria Ángeles Forner-Giner
}

check for

updates

Citation: Primo-Capella, A.;

Martínez-Cuenca, M.-R.;

Forner-Giner, M.Á. Gene Expression

under Short-Term Low Temperatures:

Preliminary Screening Method to

Obtain Tolerant Citrus Rootstocks.

Horticulturae 2021, 7, 447. https:/ /

doi.org/10.3390/horticulturae7110447

Academic Editor: María

José Rubio-Cabetas

Received: 15 September 2021

Accepted: 26 October 2021

Published: 2 November 2021

Publisher's Note: MDPI stays neutral with regard to jurisdictional claims in published maps and institutional affiliations.

Copyright: (c) 2021 by the authors. Licensee MDPI, Basel, Switzerland. This article is an open access article distributed under the terms and conditions of the Creative Commons Attribution (CC BY) license (https:/ / creativecommons.org/licenses/by/ $4.0 /)$.
Centro de Citricultura y Producción Vegetal, Instituto Valenciano de Investigaciones Agrarias (IVIA), CV-315, km. 10, 46113 Valencia, Spain; martinez_mru@gva.es (M.-R.M.-C.); forner_margin@gva.es (M.Á.F.-G.)

* Correspondence: primo_amp@gva.es; Tel.: +34-96-342-41-05; Fax: +34-96-342-40-01

Abstract: Climate change and global warming are leading to a change in weather patterns toward hot and cold waves. Citrus fruits are a tropical or subtropical crop whose growth is altered by changes in weather patterns. Thus, in the present work, two experiments are evaluated to obtain a screening method to select citrus rootstocks that help us to select new low-temperature-tolerant plant materials. One cold experiment was carried out with the Poncirus trifoliata and Citrus macrophylla rootstocks at $4{ }^{\circ} \mathrm{C}$ for $4,8,24$ and $56 \mathrm{~h}$. A second experiment was performed at $4{ }^{\circ} \mathrm{C}$ for 5 days with subsequent acclimatization lasting $0,5,10$ and $24 \mathrm{~h}$. The expression of the cold response genes CAMTA1, CAMTA3, CAMTA5, CBF1, ICE1 and COR413 IM1 was quantified. The results showed that the best rootstock selection strategy was the second experiment, as a higher expression of the genes CAMTA3, CAMTA5, CBF1 and COR413 IM1 was seen in the tolerant genotype P. trifoliata. We quantified the gene expression of proline biosynthesis P5CS1, dOAT and the proline transporters PROT1 and PROT2; the concentration of the amino acid proline in leaves was also quantified. These results once again showed that the best experiment to differentiate between tolerant and sensitive rootstocks was the second experiment with acclimation time.

Keywords: citrus; rootstock; cold stress; breeding program; abiotic stress

\section{Introduction}

Citrus is a tropical or subtropical crop that needs a certain climate to survive. Currently, due to climate change and global warming, many cold and heat waves are taking place, which strongly impact citrus fruit given their subtropical cultivation condition. Low temperature is one of the main stresses that limits crop growth, productivity and distribution [1]. For this reason, it is very important to obtain new plant material that is able to face unfavorable situations, such as cold stress. In citrus, the grafting technique is widespread and used to face abiotic stresses [2-5]. Thus, the selection of a good rootstock is important and depends on the cultivation area [6]. To start the selection of a good rootstock against low temperatures, we must first find the best way to induce stress without causing fatal plant damage. Thus, to perform the best screening for plant material selection purposes, this article presents two possible ways of inducing cold tolerance.

Plant material selection is also very important because we need to investigate to know why rootstocks are tolerant and sensitive, and to obtain their differences. It has been verified that P.trifoliata is traditionally the most tolerant rootstock to low temperatures to date, as it tolerates up to $-15{ }^{\circ} \mathrm{C}$ in leaves and up to $-20^{\circ} \mathrm{C}$ in stems $[7,8]$. Previously verified as a sensitive genotype, the lemon rootstock C.machophylla was selected as a sensitive rootstock to low temperatures [9-12].

The most immediate response to low temperatures is the molecular response, which can occur in two ways. One way is through the independent CBF activation pathway (Crepeat binding factors). It is given by the activation of COR (cold-regulated) response genes 
from an independent pathway of CBF transcription factors. Alternatively, the molecular response can be given by the dependent CBF-COR route. The CBF regulon is the central response to low temperatures. It is an activation cascade that leads to the activation of the COR response genes that depend on CBF transcription factors [13,14].

As the CBF-dependent activation pathway is the central cold response pathway, it was very interesting for us to delve deeper into it. It is known that calcium influx reaches a receptor kinase regulated by Calmodulin 1 and 2 (CRLK1 and CRLK2), and it begins a signaling cascade of the cold-specific pathway $[15,16]$. These MPKs can activate or repress the next transcription factor in the signaling pathway, ICE1 (induced from $C B F$ expression 1), which is a MYC-like helix-turn-helix transcription factor that binds the cis elements of CBF gene promoters [17-20]. CBF genes are also known as DREBs (Dehydration-Responsive Element-Binding Factors) and generally comprise three members, namely $C B F 1, C B F 2$ and $C B F 3$ (also called $D R E B 1 b, D R E B 1 c$ and $D R E B 1 a$, respectively) in Arabidopsis thaliana. However, this may vary depending on the species. For example, in poplar, the induction of four $C B F$ genes $(C B F 1, C B F 2, C B F 3, C B F 4)$ has been found in response to low temperatures [21]. Thus, $C B F$ s activate low-temperature response genes called COR, which act in the second phase of the response (minutes-hours) and also in the acclimatization phase (days-weeks), as previously mentioned.

In addition to transcription factor ICE1, other transcription factors activate the expression of CBFs; these are CAMTA factors (Calmodulin-binding transcription activator) [22]. CAMTA 1, CAMTA 2, CAMTA 3 and CAMTA 5 are known to induce CBFs. Specifically, it has been seen that CAMTA 3 and CAMTA 5 act in the first few minutes of temperature lowering and have been related to sudden (day/night) temperature changes, but not to progressive temperature changes, as in the case of seasonal changes [22,23].

We were also interested in the synthesis and degradation route of the amino acid proline. George Yelenosky et al. [8,24,25] previously postulated an important role for proline in citrus fruit that have suffered stress from low temperature. Hence, we have a marked interest in checking what happens during cold stress with proline synthesis, degradation and transport.

Proline is an amino acid that acts as an osmoprotector. It performs multiple functions in the cell, but, above all, it plays an important role in osmotic adjustment by increasing the ability to resist cell dehydration. Proline is capable of accumulating in some species such as citrus [12,24-26] in the presence of certain abiotic stresses, such as salinity, drought, waterlogging and temperature stress (heat, cold and freezing) [27-32].

Proline in plants is synthesized mainly from the amino acid glutamate, which is reduced in the cytosol to glutamate-5-semialdehyde (GSA) by pyrroline-5-carboxylate syntase 1 and 2 (P5CS1 and P5SC2), and spontaneously becomes pyrroline-5-carboxylate (P5C). P5C reductase (P5CR) reduces P5C to proline. However, proline catabolism occurs in mitochondria via proline dehydrogenase (PDH), which once again produces $\mathrm{P} 5 \mathrm{C}$ and delta 1-pyrroline-5-carboxylate dehydrogenase (P5CDH), which converts P5C into glutamate. Alternatively, proline can also be synthesized by another route from ornithine, which is transaminated in mitochondria by delta ornithine aminotransferase (dOAT) to produce GSA and P5C, which are then converted into proline [27,28,30,33].

Amino acid L-proline transport is vital for combating various abiotic stresses. Proline transport across the plasma membrane during abiotic stress is carried out by two types of transporters. The first forms part of the AAAP (amino acid/auxin permease) family, and the second is included in the APC (amino acid-polyamine choline) family. In Arabidopsis thaliana, we know of a family of transporters (PROT) related to proline transport under abiotic stress whose expression is normally associated with high proline levels in the medium. Specifically, the AtPROT1 transporter is expressed under salinity conditions [34] and is detected in the phloem of all analyzed organs, which suggests a role in long-distance L-proline transport [35]. AtPROT2 is primarily responsible for nitrogen transport during drought stress [34], and is found in the epidermis and the cortex of roots, and also in leaves after the "bite" effect. AtPROT3 expression is restricted to the epidermis of leaves [35]. 
For all these reasons, the objective of this article was to perform an experiment to allow us to induce stress tolerance due to low temperatures quickly and on a large scale to implement a screening method that obtains new tolerant citrus rootstocks. In addition, from the bibliographic data, we selected a group of genes for their rapid response to cold stress detection, and also for the synthesis and transport of the amino acid proline, which is considered important in cold tolerance at low temperatures.

\section{Materials and Methods}

\subsection{Plant Material and Growing Conditions}

Citrus macrophylla (henceforth MAC) and Poncirus trifoliata Rubidoux@ (henceforth PON) seeds were used. The testa, and partially the tegmen, were removed to not damage the embryo. They were then sterilized for $15 \mathrm{~min}$ at $2 \% v / v$ of a commercial bleach solution $(0.5 \mathrm{M} \mathrm{NaClO})$ and rinsed with 3 washes of distilled water, previously autoclaved at $120^{\circ} \mathrm{C}$ for $20 \mathrm{~min}$. Then, they were transferred to growth medium $\left(5 \mathrm{mM} \mathrm{KNO}_{3}, 5 \mathrm{mM} \mathrm{Ca}\left(\mathrm{NO}_{3}\right)_{2}\right.$, $4 \mathrm{mM} \mathrm{MgSO}_{4}, 0.6 \mathrm{mM} \mathrm{KH}_{2} \mathrm{PO}_{4}, 0.7 \mu \mathrm{M} \mathrm{MoO}_{3}, 9 \mu \mathrm{M} \mathrm{MnCl}_{2} \cdot 4 \mathrm{H}_{2} \mathrm{O}, 18 \mu \mathrm{M} \mathrm{ZnSO}_{4} \cdot 7 \mathrm{H}_{2} \mathrm{O}$, $0.40 \mu \mathrm{M} \mathrm{CuSO}_{4} \cdot 5 \mathrm{H}_{2} \mathrm{O}, 43 \mu \mathrm{M}$ Fe-EDDHA), $\mathrm{pH}$ was adjusted to 5.8 with $\mathrm{KOH}$ and $0.4 \%$ plant agar was added (Duchefa, 2031 BHaarlem, The Netherlands). The growth medium was autoclaved and placed inside $150 \times 25 \mathrm{~mm}$ tubes ( $40 \mathrm{~mL}$ per tube). Then, seeds were sown (one per tube) to germinate in a growth chamber (Sanyo MCR-350H, Sanyo Electric Biochemical Co., Osaka, Japan) at $24^{\circ} \mathrm{C} / 22^{\circ} \mathrm{C}$ in $16 \mathrm{~h}$ light $/ 8 \mathrm{~h}$ darkness, respectively, plus $250 \mu \mathrm{mol} \mathrm{m}{ }^{-2} \mathrm{~s}^{-1}$ of photosynthetic photon flux density.

\subsubsection{Experiment 1}

After 8 weeks, the treatment was carried out at $4{ }^{\circ} \mathrm{C}$ for 0 (henceforth CT-Control), 4 , 8,24 and $96 \mathrm{~h}$ with a photoperiod of $16 \mathrm{~h}$ light $/ 8 \mathrm{~h}$ darkness. For each time and genotype, 5 biological replicates of 2 plants each were used, which gave 10 seedlings per genotype and time point.

\subsubsection{Experiment 2}

After 8 weeks, all the test plants except the Control (henceforth $\mathrm{CT}$ ) plant were treated at $4{ }^{\circ} \mathrm{C}$ with a photoperiod of $16 \mathrm{~h}$ light $/ 8 \mathrm{~h}$ darkness for 5 days. Subsequently, the plants were transferred to an acclimatization chamber at $24^{\circ} \mathrm{C} / 22^{\circ} \mathrm{C}$ for $16 \mathrm{~h}$ light $/ 8 \mathrm{~h}$ darkness, respectively, where they were left for $0,5,10$ and $24 \mathrm{~h}$ until sample collection. In this case, there were 5 biological replicates of 2 plants per biological replicate, which gave 10 seedlings per genotype and time point.

\subsection{Obtaining Putative Genes}

All the putative genes in citrus were consulted in Arabidopsis thaliana and were checked in "The Arabidopsis Information Resource web" (TAIR) https:/ /www.arabidopsis.org/, accessed on 15 August 2021. A tBLASTtn for Citrus clementina was performed on the website of the International Citrus Genome Consortium, Phytozome (https: / phytozome. jgi.doe.gov/pz/portal.html, accessed on 15 August 2021) (Goodstein et al., 2012). Thus Table 1 was obtained.

Table 1. The oligonucleotides obtained for the quantification of the gene expression of the following putative genes. The annotation is shown in the format taken from GeneBank and Phytozome.

\begin{tabular}{|c|c|c|c|}
\hline GeneBank & Name & Phytozome & Primer Sequence $5^{\prime}-3^{\prime}$ \\
\hline \multicolumn{4}{|c|}{ Cold response } \\
\hline LOC18034255 & CAMTA1 & Ciclev10027833m & $\begin{array}{c}\text { FOR } 5^{\prime} \text { TTCCCGTGAAACCAAGGAGTC } 3^{\prime} \\
\text { REV } 5^{\prime} \text { CAGACATGAAGGTGTCATCATCCAA } 3^{\prime}\end{array}$ \\
\hline LOC18035748 & САMТАЗ & Ciclev10024764m & $\begin{array}{c}\text { FOR 5' TCAGTATCCAGAAGCGAGGGATC 3' } \\
\text { REV 5' TCTGCGTTGCTCAGAGCCAT } 3^{\prime}\end{array}$ \\
\hline LOC18031834 & CAMTA5 & Ciclev10004273m & $\begin{array}{l}\text { FOR } 5^{\prime} \text { GAAGAATATCGGAGGATGAAGCTGG } 3^{\prime} \\
\text { REV } 5^{\prime} \text { CCATATCTGGGTCAAGTAGCCT REV } 3^{\prime}\end{array}$ \\
\hline
\end{tabular}


Table 1. Cont.

\begin{tabular}{|c|c|c|c|}
\hline GeneBank & Name & Phytozome & Primer Sequence $5^{\prime}-3^{\prime}$ \\
\hline LOC18051975 & ICE1 & Ciclev10015052m & $\begin{array}{l}\text { FOR 5' GCCTTGGGTTGGACATTCAGCAG 3' } \\
\text { REV 5' CTGCTTGGGCAAGACATCCTGG 3' }\end{array}$ \\
\hline LOC18033409 & CBF1 & Ciclev10007068m & $\begin{array}{c}\text { FOR } 5^{\prime} \text { TGGGATGCCCAGATTGTTG } 3^{\prime} \\
\text { REV } 5^{\prime} \text { CCTCCACAATTAGACTGAGGTGGT } 3^{\prime}\end{array}$ \\
\hline LOC18053244 & COR413 IM1 & Ciclev10016585m & $\begin{array}{l}\text { FOR 5' CTCTTGGTTATTGTGGCTCCTCATC } 3^{\prime} \\
\text { REV 5' TGGCAACAACTGAACCTTGCTC } 3^{\prime}\end{array}$ \\
\hline \multicolumn{4}{|c|}{ Biosynthesis proline route } \\
\hline LOC18044634 & P5CS1 & Ciclev10030839m & $\begin{array}{l}\text { FOR 5' AAGGAAGCGGGCAAGTGGT 3' } \\
\text { REV 5' CCTCGTGGATGTATTCGACCC } 3^{\prime}\end{array}$ \\
\hline LOC18051867 & $d-O A T$ & Ciclev10015647m & $\begin{array}{l}\text { FOR } 5^{\prime} \text { TCAAGGAGAGGCTGGGGTTA } 3^{\prime} \\
\text { REV } 5^{\prime} \text { CGAACTTCTTCCCAATCAGAGG } 3^{\prime}\end{array}$ \\
\hline LOC18043556 & PROT1 & Ciclev10031324m & $\begin{array}{l}\text { FOR } 5^{\prime} \text { TGGCTGGGAGTTTCAACAGTTCTC } 3^{\prime} \\
\text { REV } 5^{\prime} \text { CAAACACCAGATTAGCACATGCCC } 3^{\prime}\end{array}$ \\
\hline LOC18047579 & PROT2 & Ciclev10020150m & $\begin{array}{l}\text { FOR 5 5' CTGGGCTTACGGCTCCAGTGTATC } 3^{\prime} \\
\text { REV 5' GTGTCAAGGGTCTCGTAAACTGGCG } 3^{\prime}\end{array}$ \\
\hline \multicolumn{4}{|c|}{ Reference genes } \\
\hline LOC18055321 & Ubiquitin & Ciclev10009771m & $\begin{array}{l}\text { FOR 5' TGGACGCTTCAGTCTGTTTG 3' } \\
\text { REV 5' TCGTCAATCACCCCTTCTTT 3' }\end{array}$ \\
\hline LOC18037526 & $\beta-A C T I N$ & Ciclev10025866m & $\begin{array}{l}\text { FOR } 5^{\prime} \text { CAGTGTTTGGATTGGAGGATCA } 3^{\prime} \\
\text { REV } 5^{\prime} \text { TCGCCCTTTGAGATCCACAT } 3^{\prime}\end{array}$ \\
\hline
\end{tabular}

\subsection{RNA Isolation and Gene Quantification by RT-PCR}

Leaf samples were collected, placed in liquid $\mathrm{N}_{2}$ and stored at $-80{ }^{\circ} \mathrm{C}$. RNA was extracted from $100 \mathrm{mg}$ of tissue using the RNase Plant Mini Kit (Qiagen, CA, USA) with an RLT- $\beta$-mercaptoethanol buffer (Merck, Burlington, MA, USA). Genomic DNA contamination was removed by the RNase-Free DNase Set Kit (Qiagen, CA, USA) from column digestion, according to the manufacturer's instructions. Purified RNA $(1 \mu \mathrm{g})$ was used to perform the reverse transcription reaction with the enzyme (SuperScript III Life Technologies, Carlsbad, CA, USA) in a total volume of $20 \mu \mathrm{L}$. cDNA was diluted 50 times and $2 \mu \mathrm{L}$ were used as a template for the RT-PCR reaction in a final volume of $20 \mu \mathrm{L}$. The quantitative RT-PCR reaction was performed in a StepOnePlus Real-Time PCR System thermal cycler (Life Technologies, Carlsbad, CA, USA) using Ex Taq polymerase (TliRNase H plus) (Takara Europe, SAS, Saint Germain en Laye, FR) with TB Greenpremix. The PCR program consisted of $10 \mathrm{~min}$ at $95^{\circ} \mathrm{C}$, followed by 40 cycles of $15 \mathrm{sec}$ at $95^{\circ} \mathrm{C}$ and $1 \mathrm{~min}$ at $60^{\circ} \mathrm{C}$. Reaction specificity was taken as the presence of a single peak on the dissociation curve and with amplified product size estimates, which was verified from agarose electrophoresis. The transcripts of genes CiclevActin and CiclevUBC4, amplified with specific oligonucleotides, were used as the reference genes (Table 1) [36,37]. The calculations of the simple ANOVA and linear regression of the $\mathrm{Ct}$ (Cycle Threshold) test values were taken from [38] to examine the variation of our reference genes. The normalization factor of the reference genes was calculated using the value of the geometric mean of both genes [38]. Relative expression was measured by the standard curve procedure with five dilution points [39]. The results were obtained with the average of the 3 independent biological samples with 3 technical replicates of each one of them.

\subsection{Proline Quatification}

The free proline concentration in leaves was determined according to $\mathrm{Hu}$, Delauney and Verna [40]. Samples were measured at 0, 8, 24 and $96 \mathrm{~h}$ at Experiment 1 and at CT, 0, 5, 10 and $24 \mathrm{~h}$ at Experiment 2 in frozen and lyophilized leaves. Then, $250 \mathrm{mg}$ was weighed and homogenized (Vortex) in $1.5 \mathrm{~mL}$ of sulfosalicylic acid (3\%) for $1 \mathrm{~min}$, centrifuged at 14,000 rpm for 5 min (Eppendorf Centrifuge 5810R, AG, Hamburg, Germany), and the supernatant was stored at $4{ }^{\circ} \mathrm{C}$. An aliquot $(0.2 \mathrm{~mL})$ was incubated with $0.5 \mathrm{~mL}$ of sulfosalicylic acid (3\%), $0.7 \mathrm{~mL}$ of reactive ninhydrin acid reagent (ninhydrin, phosphoric 
acid $6 \mathrm{M}$, glacial acetic acid $60 \%$ ) and $0.6 \mathrm{~mL}$ of glacial acetic acid (99\%) in a dry bath at $100{ }^{\circ} \mathrm{C}$ for $1 \mathrm{~h}$ (Thermostatic Bath BD, Bunsen SA, Humanes, Spain). Samples were cooled in an ice bath for $15 \mathrm{~min}$ and absorbance was measured at $520 \mathrm{~nm}$ (Lambda 25, PerkinElmer, Shelton, CT, USA).

\subsection{Statistical Analyses}

For the statistical analyses, the proline quantification values were the mean of 5 independent replicates of 2 plants each per time point. The RT-PCR values were the mean and standard deviation of 3 biological replicates and 3 technical replicates per plant. Data were submitted to an analysis of variance (multifactor ANOVA) using Statgraphics Centurion, version 16.1 (Statistical Graphics, Englewood Cliffs, NJ, USA) prior to testing for normality and homogeneity. When the ANOVA showed a statistical effect, means were separated by least significant differences (LSD) at $p<0.05$.

\section{Results}

\subsection{Experiment 1}

3.1.1. Gene Expression of the Putative Low-Temperature Response Genes in the Short Term

The quantification of the gene expression of the low-temperature response genes that are known to be key in the first cold exposure moments was carried out. These response genes are shown in Figure $1 \mathrm{a}-\mathrm{f}$ for the PON and MAC genotypes. The CAMTA genes (Figure 1a-c)—considered to be "cold shock genes"-discreetly increased, albeit with differences between the two rootstocks. CAMTA1 expression increased with time in both genotypes; it was 2 times higher at $56 \mathrm{~h}$ vs. $0 \mathrm{~h}$ cold exposure, with no differences between the rootstocks. CAMTA3 expression was higher after $56 \mathrm{~h}$ of exposure to low temperature in the PON seedlings; it was significantly ( 3 times) higher than in the MAC seedlings. CAMTA5 expression was not entirely conclusive for either rootstock, but after $8 \mathrm{~h}$ of cold exposure, its expression in the PON genotype was 2 times higher than that in the MAC seedlings. The transcription factor ICE1 results were also discreet. After $4 \mathrm{~h}$ of cold exposure, the expression increased in both genotypes from 1 time to 1.5 times in PON and from 0.25 times to 0.6 times in MAC vs. $0 \mathrm{~h}$. In both cases, the expression was repressed at later cold treatment hours. The expression of the putative gene CBF1 was more interesting for the PON rootstock, as it increased by 9 times after $4 \mathrm{~h}$ of cold exposure compared to the initial times by 4 -fold after $56 \mathrm{~h}$ of exposure. However, the MAC genotype seedlings did not induce the cold response through the CBF1 gene, or no induction was detected. Figure $1 \mathrm{f}$ shows the expression of the response gene COR413 IM1, which was activated by CBF transcription factors. In the PON seedlings, the expression was repressed 4 times at 4,8 and $24 \mathrm{~h}$ of cold exposure in relation to the initial hours of cold exposure. However, the expression increased again at $56 \mathrm{~h}$ of cold exposure. COR413 IM1 expression did not change over time in the MAC rootstock.

3.1.2. Gene Expression of the Synthesis and Transport of Proline and Its Quantification in Experiment 1

In the present test, our aim was to verify if the biosynthesis pathway and the concentration of the amino acid proline were induced by short-term cold exposure. The gene expression of the two main genes for proline synthesis in stress situations (Figure 2a,b) are P5CS1 and dOAT. P5CS1 expression (Figure 2a) increased in both cases with exposure time, and expression was significantly higher at $24 \mathrm{~h}$ of exposure in the MAC-sensitive rootstock, with 2 times induction compared to its $\mathrm{CT}$ at $0 \mathrm{~h}$ of cold exposure. The putative $d O A T$ gene (Figure 2b) also tended to increase with hours of cold exposure and peaked at $24 \mathrm{~h}$, when MAC was more significantly expressed than PON, with an increase in expression from 1.6 times at $0 \mathrm{~h}$ to 2.5 times at $24 \mathrm{~h}$. However, $d O A T$ expression decreased in both cases after $56 \mathrm{~h}$ of exposure to low temperature. 

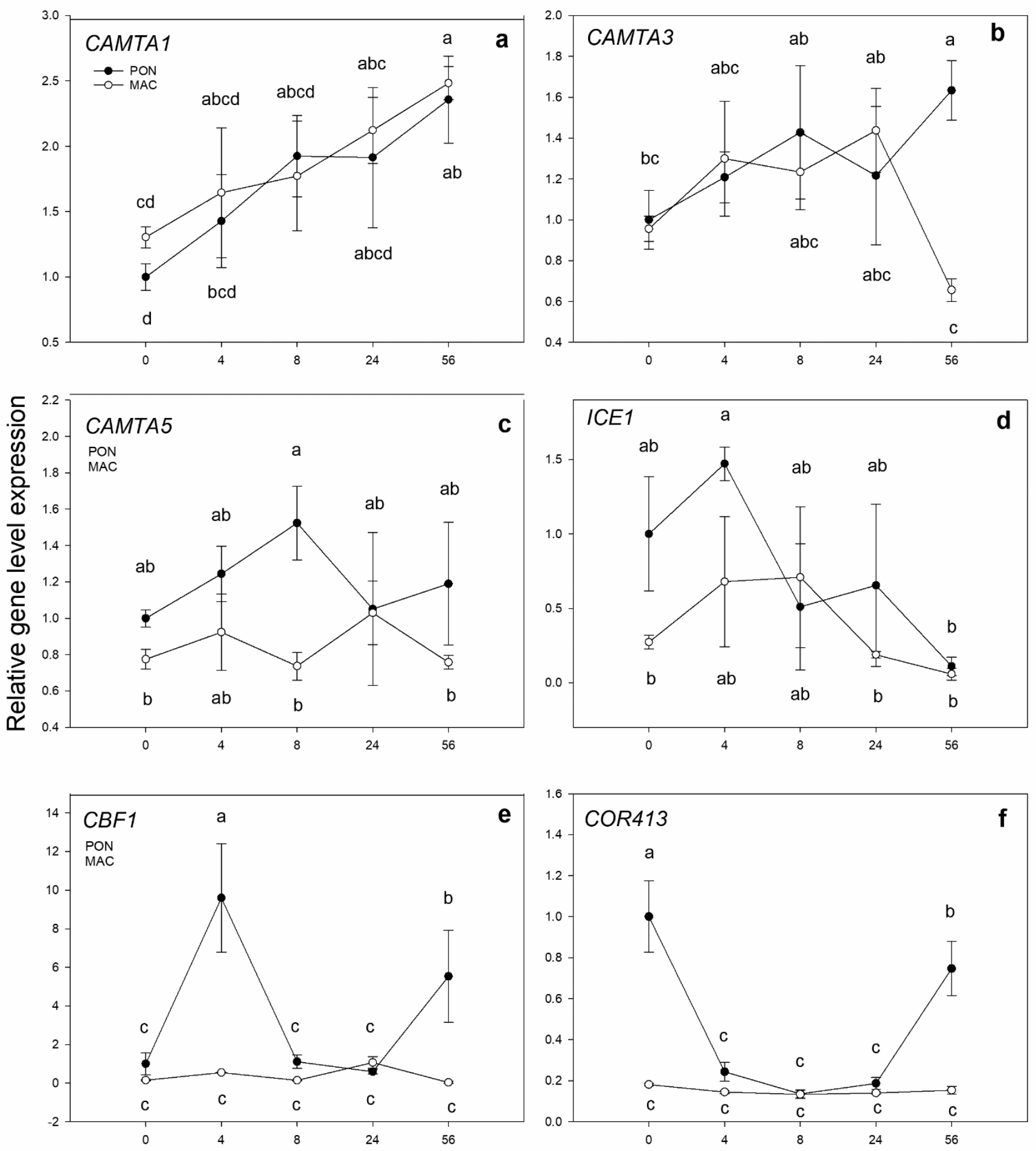

\section{Hours}

Figure 1. Gene expression of the putative low-temperature response genes in leaves. The 2-month-old Poncirus trifoliata (PON) and Citrus macrophylla (MAC) seedlings were subjected to $4{ }^{\circ} \mathrm{C}$ for $0,4,8,24$ and $56 \mathrm{~h}$. (a-c) respectively correspond to putative genes CAMTA1 (Ciclev10027833m), CAMTA3 (Ciclev10024764m) and CAMTA5 (Ciclev10004273m). (d,e) respectively correspond to the central transcription factors of cold response ICE1 (Ciclev10015052m) and CBF1 (Ciclev10007068m). (f) Putative COR413 IM1 gene expression (Ciclev10016585m). The values shown represent the mean $\pm \mathrm{SE}$ between 3 biological replicates $(n=3)$ and 3 technical replicates. Letters indicate the effect of treatment at different times, which was tested by an LSD test of the multiple ANOVA. 

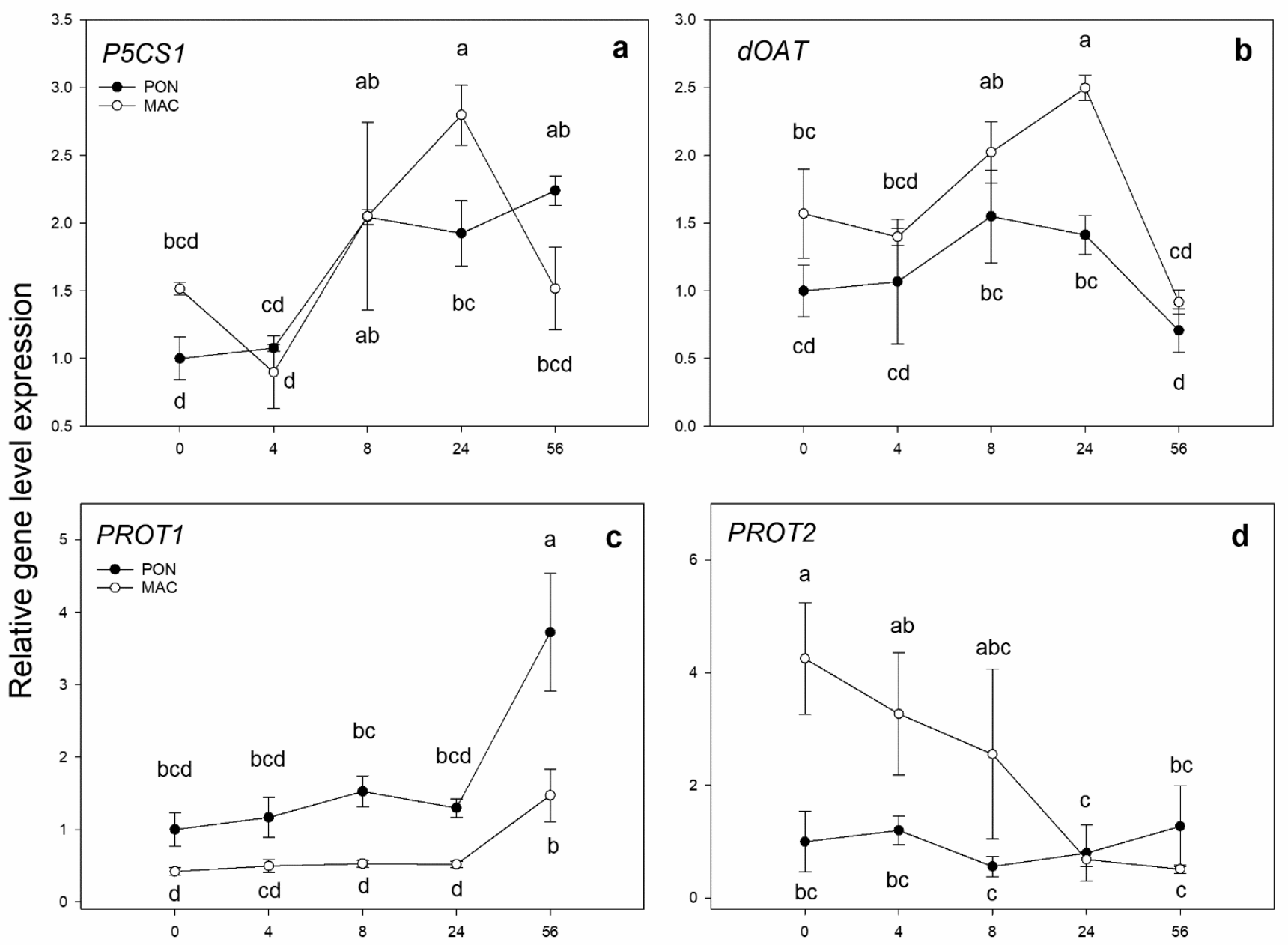

Hours

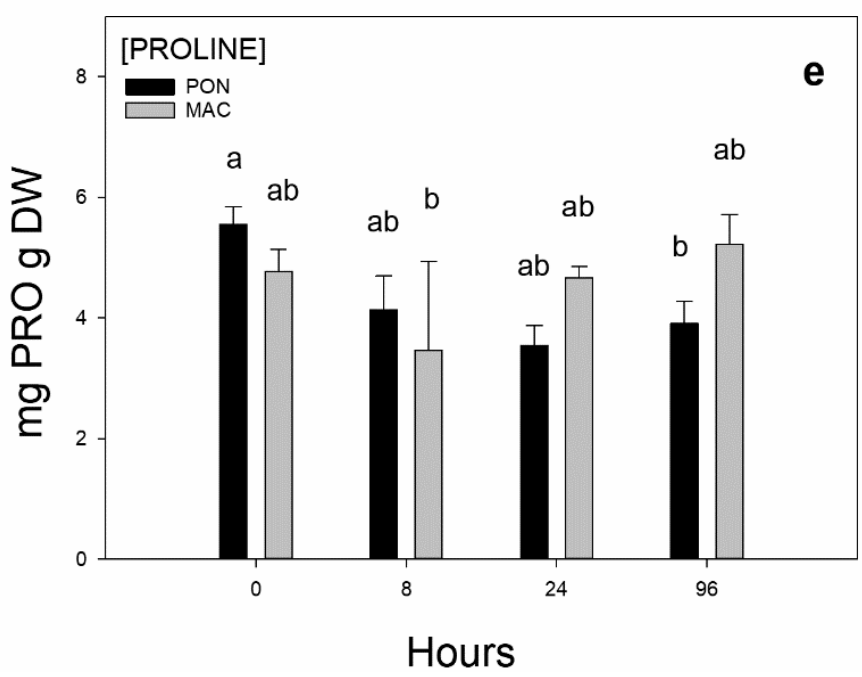

Figure 2. Gene expression of the putative genes of the proline biosynthesis and transport pathway in leaves. The 2month-old Poncirus trifoliata (PON) and Citrus macrophylla (MAC) seedlings were subjected to $4{ }^{\circ} \mathrm{C}$ for $0,4,8,24$ and $56 \mathrm{~h}$. $(\mathbf{a}, \mathbf{b})$ respectively correspond to putative proline synthesis genes P5CS1 (Ciclev10030839m) and dOAT (Ciclev10015647m). (c,d) respectively correspond to proline transporters PROT1 (Ciclev10031324m) and PROT2 (Ciclev10020150m). (e) Quantification of the amino acid proline in leaves. Values represent the mean $\pm S E$ among 3 biological replicates $(n=3), 5$ replicates for proline quantification $(n=5)$ and 3 technical replicates for both. The letters indicate the effect of treatment at different times, which was tested with an LSD test of the multiple ANOVA. 
The expressions of the two putative proline transporters PROT1 and PROT2 were also quantified (Figure 2c,d). PROT1 expression (Figure 2c) began to increase after $56 \mathrm{~h}$ of low temperature exposure. At $56 \mathrm{~h}$ of cold exposure, $\mathrm{PON}$ expression significantly increased (by 3 times), while the expression in the MAC genotype increased by 2 times at $56 \mathrm{~h}$. With PROT2 (Figure 2d), the expression decreased by up to 4 times in the MAC rootstock over time $(56 \mathrm{~h})$. In contrast, in the PON genotype, the expression of proline transporter PROT2 did not change.

To see the impact of the biosynthesis proline genes, the proline concentration in the leaves was also quantified (Figure 2e). No clear trend in proline concentration was observed for either rootstock under these stress conditions, probably because the exposure time was too short to detect a possible rise in the osmolyte concentration.

\subsection{Experiment 2}

3.2.1. Gene Expression of the Putative Low-Temperature Response Genes after an Acclimatization Period

Here, our aim was to obtain information for early response genes during acclimatization to see their induction and how long it would take for that induction to disappear, and to find any difference between rootstocks. Figure 3a shows the expression of the putative gene CAMTA1, which did not demonstrate significant differences between rootstocks. Its expression increased 2 times at $0 \mathrm{~h}$ and $5 \mathrm{~h}$ of acclimatization, and it returned to the CT values after $10 \mathrm{~h}$. The expression of the putative gene CAMTA3 (Figure 3b) was 2 times higher in the PON genotype than in MAC at $0 \mathrm{~h}$ of acclimatization time. The expression of the putative gene CAMTA5 (Figure 3c) significantly increased (by almost 9 times) in the PON rootstock after being exposed for 5 days to low temperature at $0 \mathrm{~h}$ of acclimatization. In the MAC genotype, this increase was not as high; it increased by 3 times. However, the expression at $5 \mathrm{~h}$ of acclimatization decreased, and it reached the CT values at $10 \mathrm{~h}$ of acclimatization in both genotypes. As in the previous experiment, ICE1 expression (Figure 3d) was not conclusive. After cold treatment at $0 \mathrm{~h}$ of acclimatization, the ICE1 expression in the PON rootstock was repressed. However, the expression in the MAC genotype did not change over time. Putative gene $C B F 1$, the central transcription factor of cold response (Figure 3e), displayed a very interesting expression pattern; after the $4{ }^{\circ} \mathrm{C}$ treatment, its expression increased significantly at $0 \mathrm{~h}$ of acclimatization in the PON rootstock (by 27 times) vs. the $\mathrm{CT}$, while the expression did not change in MAC. With the acclimatization process, CBF1 expression lowered to the CT values in both rootstocks. The expression of the putative gene COR413 IM1 (Figure 3f) increased by 9 times at 5 and $10 \mathrm{~h}$ of acclimatization vs. the CT in PON plants. However, in the MAC rootstock, the expression increased by about 2 times at 10 and $24 \mathrm{~h}$ after acclimatization, but was lower than in the PON rootstock. 

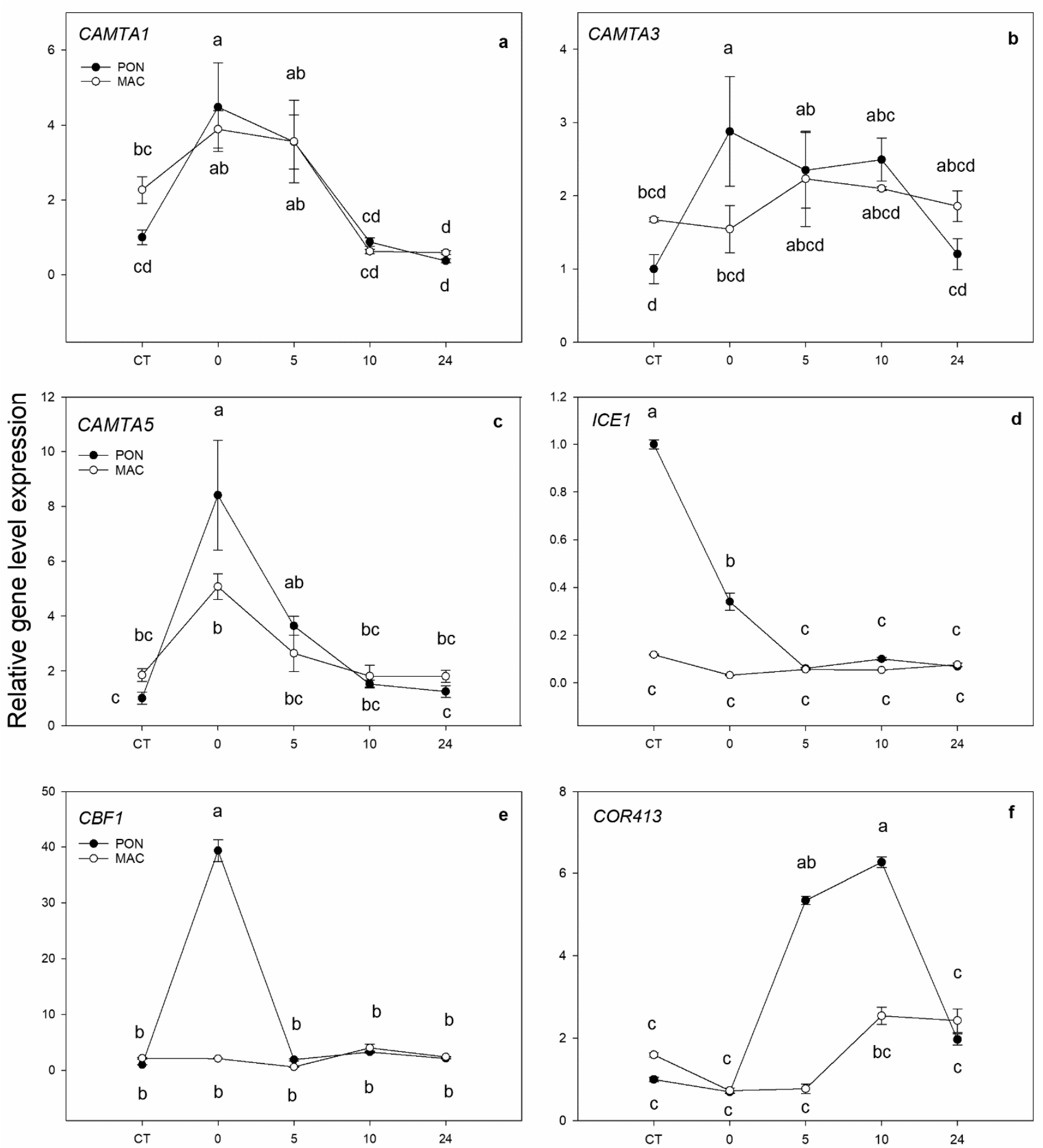

\section{Acclimatization hours}

Figure 3. Gene expression of the putative low-temperature response genes in leaves. The 2-month-old Poncirus trifoliata (PON) and Cirtus macrophylla (MAC) seedlings were subjected to $4{ }^{\circ} \mathrm{C}$ for 5 days and subsequently acclimatized for $0,5,10$ and $24 \mathrm{~h}$ at $24{ }^{\circ} \mathrm{C} / 22{ }^{\circ} \mathrm{C}$ in a photoperiod of $16 \mathrm{~h}$ light $/ 8 \mathrm{~h}$ darkness. Control group (CT) remained at $24{ }^{\circ} \mathrm{C} / 22{ }^{\circ} \mathrm{C}$ in a photoperiod of $16 \mathrm{~h}$ light $/ 8 \mathrm{~h}$ darkness during the experiment. (a-c) respectively correspond to putative genes CAMTA1 (Ciclev10027833m), CAMTA3 (Ciclev10024764m) and CAMTA5 (Ciclev10004273m). (d,e) respectively correspond to the central transcription factors of cold response ICE1 (Ciclev10015052m) and CBF1 (Ciclev10007068m). (f) The expression of putative gene COR413 IM1 (Ciclev10016585m). Values represent the mean \pm SE between 3 biological replicates $(n=3)$ and 3 technical replicates. Letters indicate the effect of treatment at different times, which was tested with an LSD test of the multiple ANOVA. 
3.2.2. Gene Expression of the Synthesis and Transport of Proline and Its Quantification in Experiment 2

We also aimed to evaluate what took place on the proline synthesis and transport pathway during the acclimatization process. The expression of the synthesis gene P5CS1 (Figure 4a) increased by 5 times compared to the CT at 0,5 and $10 \mathrm{~h}$ of acclimatization. After $24 \mathrm{~h}$ of acclimatization, the expression of P5CS1 in PON decreased to the initial values. The expression of the MAC rootstock increased during acclimatization and peaked after $10 \mathrm{~h}$ of acclimatization. The expression of the putative proline synthesis gene $d O A T$ (Figure 4b) progressively increased by between 2 and 3 times in PON, and peaked at $10 \mathrm{~h}$ of acclimatization. The MAC rootstock, however, had a very different expression pattern from PON; its expression increased by 6 times after $5 \mathrm{~h}$ of acclimatization and it went back to the initial values $24 \mathrm{~h}$ after acclimatization. The expression of the putative PROT1 transporter is shown below. It is related to long-distance proline transport or phloem transport, and to the PROT2 transporter, which is related to root-specific proline transport. The expression of the putative gene PROT1 (Figure 4c) also displayed a very different expression pattern between MAC and the tolerant PON rootstock. The expression of transporter PROT1 in PON was progressive and peaked by about 3 times after $10 \mathrm{~h}$ of acclimatization. However, in the MAC genotype, the expression increased by 6 times at $0 \mathrm{~h}$ of acclimatization compared to its CT. The expression of the putative PROT2 transporter (Figure 4d) was repressed with the low-temperature treatment in MAC and recovered its initial values at $24 \mathrm{~h}$ after acclimatization. However, the expression of the PON rootstock did not change during our experiment, and its relative expression was close to 0. Finally, Figure 4e shows the concentration of the amino acid proline in leaves. Given the expression of the proline synthesis genes (both P5CS1 and dOAT), we expected a higher concentration of the proline amino acid in the PON leaves than in MAC. However, the proline concentration was significantly higher in the MAC rootstock in the CT at 0 and $5 \mathrm{~h}$ of acclimatization. After $24 \mathrm{~h}$ of acclimatization, the amino acid proline concentration was significantly higher in PON than in MAC, which confirms that proline concentration needs more than $56 \mathrm{~h}$ of cold stress (as in Experiment 1) for its concentration to increase in leaves.

As previously indicated, the expression of transporters was restricted to certain tissues or functions. The PROT1 transporter has been shown to be expressed in phloem, which is associated with long-distance transport. However, the PROT2 transporter has been seen to be expressed primarily in roots. Thus, we decided to perform the gene quantification of putative genes PROT1 and PROT2 in roots in Experiment 2 (Figure 5). In the putative gene PROT1 (Figure 5a), the expression in both rootstocks was not clear, as each genotype demonstrated a very different expression pattern. PROT1 expression in the MAC genotype was repressed by 10 times with cold treatment at $0 \mathrm{~h}$ of acclimatization. The PON rootstock expression remained throughout the trial. For the expression of the putative gene PROT2 (Figure 5b), the MAC rootstock displayed no expression changes. However, PON did not significantly increase transporter synthesis during the low-temperature treatment, and the basal gene expression level was about 5 times higher than in the MAC roots. Finally, the quantification of the amino acid proline in roots did not give any significant results because it did not change over time (Figure 5c). 

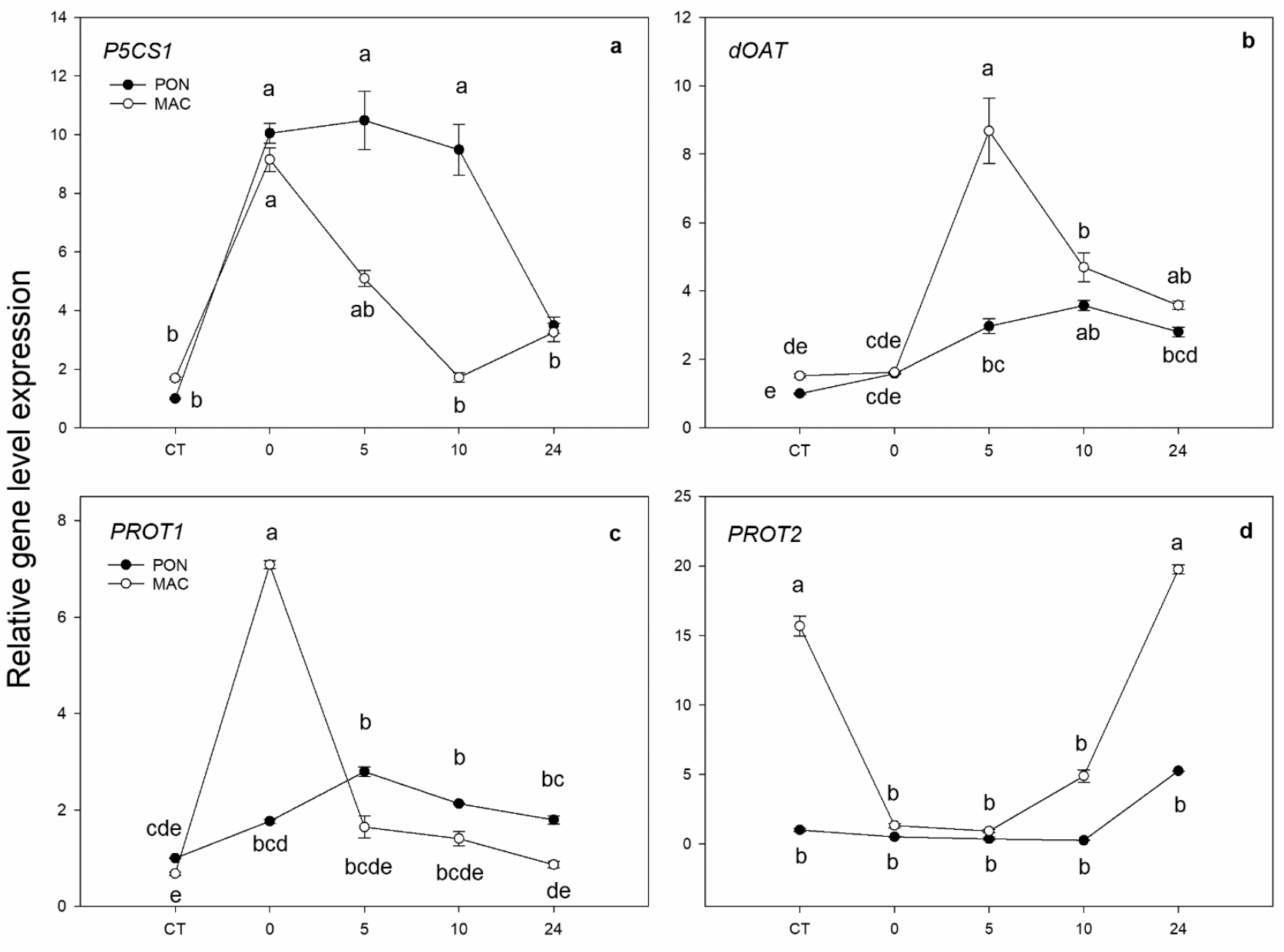

Acclimatization hours

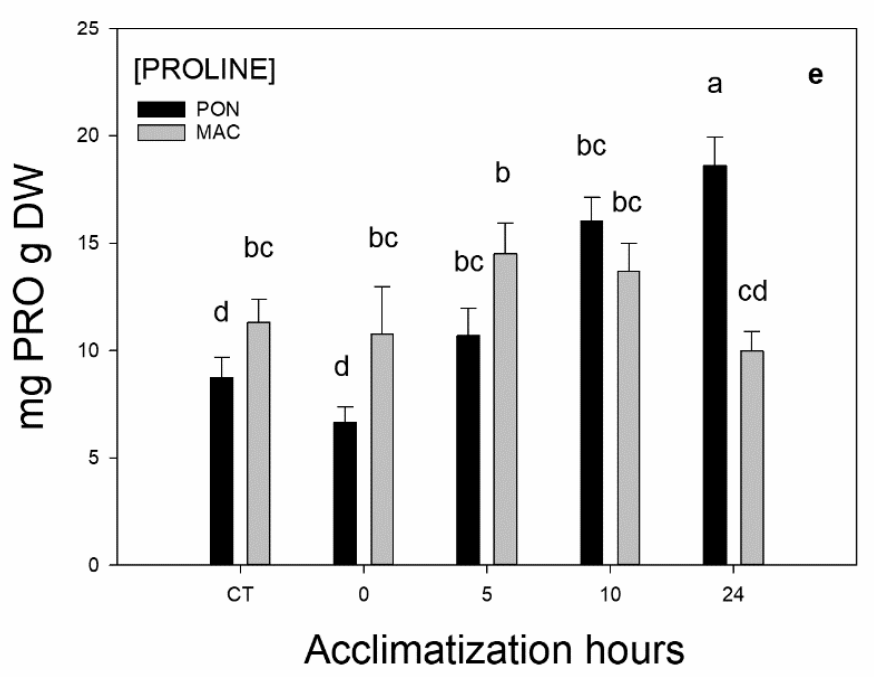

Figure 4. Gene expression of the putative genes of the proline synthesis and transport pathway in leaves. The 2-month-old Poncirus trifoliata (PON) and Citrus macrophylla (MAC) seedlings were subjected to $4{ }^{\circ} \mathrm{C}$ for 5 days and subsequently acclimatized for $0,5,10$ and $24 \mathrm{~h}$ at $24^{\circ} \mathrm{C} / 22^{\circ} \mathrm{C}$ in a photoperiod of $16 \mathrm{~h}$ light $/ 8 \mathrm{~h}$ of darkness. Control group (CT) remained at $24{ }^{\circ} \mathrm{C} / 22{ }^{\circ} \mathrm{C}$ in a photoperiod of $16 \mathrm{~h}$ light $/ 8 \mathrm{~h}$ darkness during the experiment. (a,b) respectively correspond to putative proline synthesis genes P5CS1 (Ciclev10030839m) and $d O A T$ (Ciclev10015647m). (c,d) respectively correspond to proline transporters PROT1 (Ciclev10031324m) and PROT2 (Ciclev10020150m). (e) Quantification of the amino acid proline in leaves. Values represent the mean $\pm \mathrm{SE}$ among 3 biological replicates $(n=3)$ for gene quantification, 5 replicates for proline quantification $(n=5)$ and 3 technical replicates for both. Letters indicate the effect of treatment at different times, which was tested with an LSD test of the multiple ANOVA. 

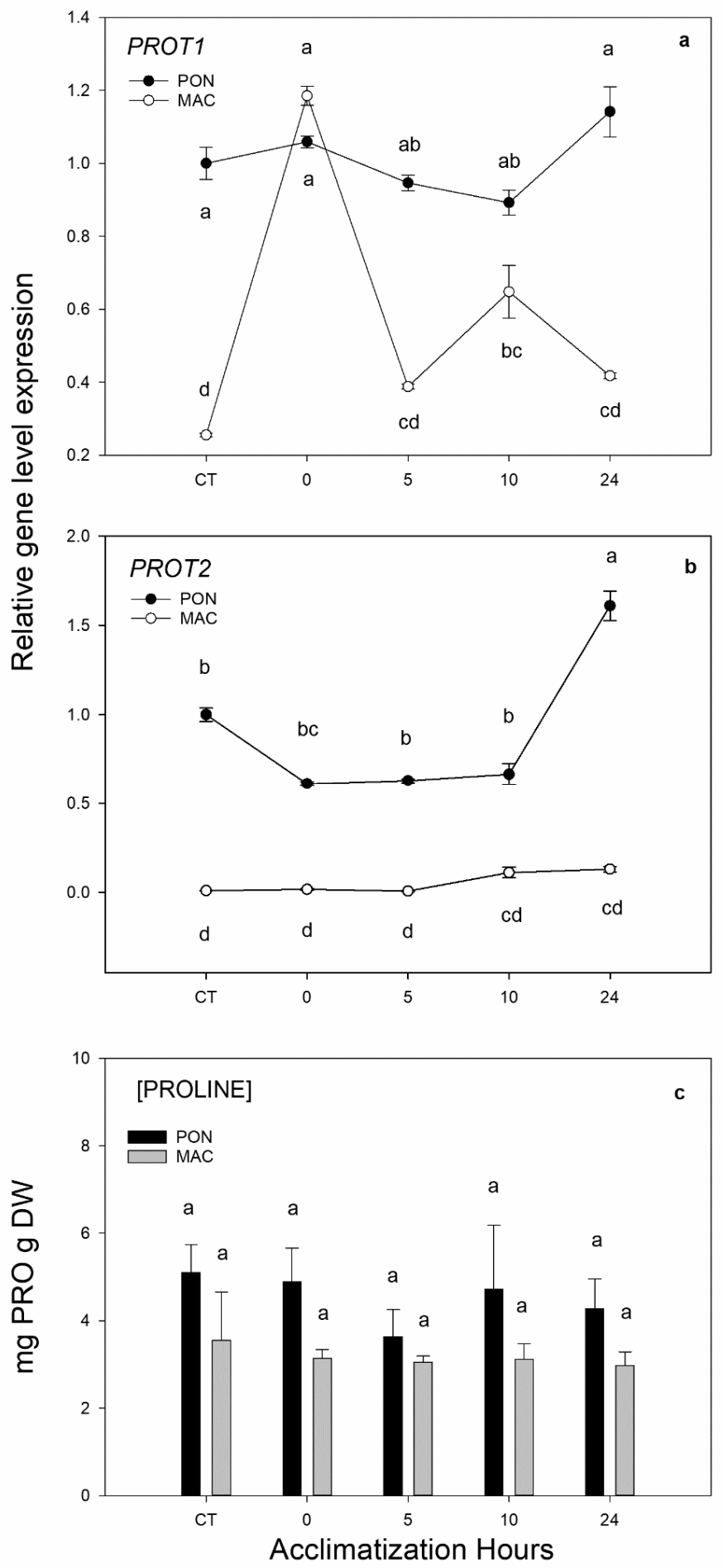

Figure 5. Gene expression of putative genes PROT1 (Ciclev10031324m) and PROT2 (Ciclev10020150m) in roots. The 2-month-old Poncirus trifoliata (PON) and Citrus macrophylla (MAC) seedlings were subjected to $4{ }^{\circ} \mathrm{C}$ for 5 days and subsequently acclimatized for $0,5,10$ and $24 \mathrm{~h}$ at $24{ }^{\circ} \mathrm{C} / 22{ }^{\circ} \mathrm{C}$ in a photoperiod of $16 \mathrm{~h}$ light $/ 8 \mathrm{~h}$ darkness. Control group $\left(\mathrm{CT}\right.$ ) remained at $24{ }^{\circ} \mathrm{C} / 22{ }^{\circ} \mathrm{C}$ in a photoperiod of $16 \mathrm{~h}$ light $/ 8 \mathrm{~h}$ darkness during the experiment. $(\mathbf{a}, \mathbf{b})$ respectively correspond to the expression of putative genes PROT1 and PROT2 in roots. (c) Quantification of the amino acid proline in roots. Values represent the mean \pm SE among 3 biological replicates $(n=3)$ for gene quantification, 5 replicates for proline quantification $(n=5)$ and 3 technical replicates for both. Letters indicate the effect of treatment at different times, which was tested with an LSD test of the multiple ANOVA. 


\section{Discussion}

As previously indicated, we were interested in knowing the rapid response of citrus rootstocks to low temperature. The induction of a response at low temperature in the seedlings of citrus rootstocks was carried out by two experiments. In the first experiment, plants were subjected to low temperature stress $\left(4^{\circ} \mathrm{C}\right)$ at different progressive times $(0$, $4,8,24$ and $56 \mathrm{~h}$ ). In this case, we aimed to see the rapid response of rootstocks to low temperatures. However, in Experiment 2, all the seedlings were subjected to the same stress for 5 days. Stress was subsequently removed and samples were taken at different times once stress had passed (acclimatization to the $\mathrm{CT}$ situation). In addition to the rapid response at low temperatures, it was also possible to see how plants recovered and returned to their initial situation, thus providing more information than in the previous case.

Rapid response genes were quantified in both experiments, and fairly consistent results between experiments were obtained (Figures 1 and 3). In both experiments, a higher expression was found in the PON genotype of the putative genes CAMTA3, CAMTA5 and $C B F 1$. Therefore, the previous selection of these three response genes in both Experiment 1 and Experiment 2 could discriminate tolerant genotypes from sensitive ones. This result does not mean that the only main inducers of the CBF-dependent regulon were CAMTA3 and CAMTA5 in this case. In fact, there is a large battery of COR inductors, and only a few are known to act through the CBF-dependent pathway [41-43].

We expected a marked induction of the ICE1 putative gene because it is the most direct and known activator in the literature regarding the CBF regulon [17,44]. In our case, the expression was not clear in either experiment; its expression in the sensitive genotype did not change with time and its expression tended to be repressed in PON. This event could have occurred for two reasons. On the one hand, the putative gene selected as ICE1 has been attributed to another gene that is not really ICE1, or, in citrus, this transcription factor acts differently from that known in other species such as Arabidopsis thaliana. The second reason, and the most probable one, is because the protein that codes for the ICE1 gene undergoes post-translational modifications and its regulation is carried out by other factors. ICE1 repression occurs on the one hand by the phosphorylation of MPK3/ 6 to reduce the stability of ICE1. This phosphorylation, carried out by MPKs, leads ICE1 to the proteasome [16,45]. On the other hand, ICE1 can also be phosphorylated by transcription factor OST1, whose phosphorylation, in this case, avoids the interaction with high osmotic response "RING FINGER" gene1, HOS1, which adds molecules of ubiquitin to ICE1 and sends it to the proteasome for degradation $[46,47]$. There is another factor, namely SUMO E3 ligase, SIZ1, which mediates the sumoylation of ICE1 at lysine 393 (Lys393) and, thus, reduces the previous polyubiquitination carried out by HOS1 [20]. Therefore, the gene expression of transcription factor ICE1 and its protein function are compromised by several factors.

The CBF1 gene had a high expression in both Experiment 1 at $4 \mathrm{~h}$ and at $56 \mathrm{~h}$, and in Experiment 2, after 5 days of cold treatment for the tolerant rootstock. However, the expression in the MAC genotype did not change in either experiment. Thus, it can be stated that the expression pattern of the CBF1 gene in tolerant citrus takes place both within hours of induction (rapid response) and after some days (long-term or acclimatization). This is because $C B F$ genes are controlled by different transcription factors, which keep them active in different situations. This also occurs with CAMTA genes, which are inducers of the faster response motivated by plasma membrane rigidification, which implies an entry of cytosolic $\mathrm{Ca}^{+2}$ and activates CAMTA transcription factors by a still unknown inducer $[22,23,48-50]$. $C B F$ genes are also controlled by those genes that intervene in circadian cycle maintenance and, therefore, by light-related genes, such as some phytochromes [51,52], or by floweringrelated genes, such as SOC1 [53].

The COR413IM1 protein in the PON rootstock began to be synthesized after $56 \mathrm{~h}$ of cold exposure in the first experiment. Hence, its expression is understood to take place in the low-temperature acclimatization phase. However, in the second experiment, the PON rootstock, COR413IM1, began to be synthesized especially during the acclima- 
tization period to the $\mathrm{CT}$ temperatures after 5 and $10 \mathrm{~h}$. The expression pattern was not as clear as in CAMTA3, CAMTA5 and CBF1, but it was interesting. COR413IM1 forms part of a group of genes of the COR (cold-regulated) family that code for integral membrane proteins and perform an unclear function. They are grouped into two groups, COR413TM/IM (by the thylakoid membrane/inner chloroplast membrane) and COR413PM (by the plasma membrane) [54]. One of the functions that has been suggested in A. thaliana and Physcomytrella patens is that COR413IM1 can alter the distribution of the metabolites involved in physiological processes to accumulate the proteins involved in the metabolism of fatty acids, fructose, starch and sucrose $[55,56]$. This metabolism adjustment in stressful situations is believed to act as a transporter or to interact physically or functionally with other metabolic transporters by regulating their activity [57]. Thus, in our experiments, the gene expression pattern of the putative gene COR413IM1 seems to correspond to the possible gene function that has been attributed to it, and this gene is expressed in the acclimatization phase by regulating metabolic processes, which would make it useful in our screening protocol.

The premise of the first studies carried out in the 1990s on citrus rootstocks in cold stress was that the synthesis of the amino acid proline was of vital importance for citrus tolerance $[8,12,26]$. For this reason, we decided to quantify the concentration and gene expression of the most important putative genes for proline synthesis and transport. The expression of the putative genes for proline synthesis (P5CS1 and $d O A T$ ) did not correspond to the concentration of the proline in leaves in the first experiment. This is not uncommon, as the synthesis of enzymes is not as fast as gene induction. Therefore, the rise in proline concentration can occur later, as in our second experiment. With transporters, PROT1 and PROT2 did not yield robust results for these genes to be included in our breeding program, but did provide us with information on their function in different rootstocks. The main PROT2 transporter function is performed in roots [34]. Thus, it would seem that in a basal way, the PROT2 transporter is more expressed in the PON genotype than in MAC, despite the slight repression in both the leaves and roots in the presence of low temperature. In several species facing different abiotic stresses, it has been seen how the application of proline in irrigation increases tolerance to stress [58-63]. Therefore, the fact that the PROT2 transporter has a higher basal gene expression in PON made us think that it could attempt to capture proline/betaine from the medium (substrate), suggesting that the amino acid proline probably plays an important role in tolerance at low temperatures in citrus fruit. Notwithstanding, we did not consider that putative genes for proline synthesis and transport were suitable for our screening program.

\section{Conclusions}

The best experiment for tracking low-temperature-tolerant citrus rootstock was the second experiment, which applied stress at $4{ }^{\circ} \mathrm{C}$ for 5 days and acclimatization at $0,5,10$ and $24 \mathrm{~h}$.

The genes selected as screening candidates were the putative genes CAMTA3, CAMTA5, CBF1 and COR413IM1.

Despite not obtaining the induction of putative genes for proline synthesis and transport in short times, we cannot rule out a possible important osmolyte in the response to cold given the basal expression of the PROT2 transporter in the Poncirus trifoliata rootstock.

Author Contributions: A.P.-C. and M.-R.M.-C. planned and carried out the experiments; A.P.-C., writing-original draft preparation; M.-R.M.-C., review and editing; M.Á.F.-G., investigation, supervision, funding acquisition and review. All authors have read and agreed to the published version of the manuscript.

Funding: This study was cofunded by the Ministerio de Ciencia e Innovación (RTI2018-098379-RI00) and the European Union through the European Regional Development Fund (ERDF) of the Generalitat Valenciana 2014-2020 (IVIA-51913).

Institutional Review Board Statement: Not applicable. 
Informed Consent Statement: Not applicable.

Data Availability Statement: The study did not report any data availability statement.

Acknowledgments: We thank Carmen Casamayor and Jesús Asensi for their laboratory and technical support.

Conflicts of Interest: The authors declare no conflict of interest.

\section{References}

1. Attaway, J.A. A History of Florida Citrus Freezes; Florida Science Source: Longboat Key, FL, USA, 1997; ISBN 978-0-944961-03-2.

2. Martínez-Cuenca, M.-R.; Iglesias, D.J.; Forner-Giner, M.A.; Primo-Millo, E.; Legaz, F. The effect of sodium bicarbonate on plant performance and iron acquisition system of FA-5 (Forner-Alcaide 5) citrus seedlings. Acta Physiol. Plant. 2013, 35, $2833-2845$. [CrossRef]

3. Martínez-Cuenca, M.-R.; Primo-Capella, A.; Forner-Giner, M.A. Key role of boron compartmentalisation-related genes as the initial cell response to low B in citrus genotypes cultured in vitro. Hortic. Environ. Biotechnol. 2019, 60, 519-530. [CrossRef]

4. Martínez-Cuenca, M.-R.; Quiñones, A.; Forner-Giner, M.Á. Screening of 'King' mandarin (Citrus nobilis Lour) $\times$ Poncirus trifoliata ((L.) Raf.) hybrids as citrus rootstocks tolerants to iron chlorosis. Sci. Hortic. 2016, 198, 61-69. [CrossRef]

5. Primo-Capella, A.; Martínez-Cuenca, M.-R.; Gil-Muñoz, F.; Forner-Giner, M.A. Physiological characterization and proline route genes quantification under long-term cold stress in Carrizo citrange. Sci. Hortic. 2021, 276, 109744. [CrossRef]

6. Forner-Giner, M.; Alcaide, A.; Primo-Millo, E.; Forner, J. Performance of 'Navelina' orange on 14 rootstocks in Northern Valencia (Spain). Sci. Hortic. 2003, 98, 223-232. [CrossRef]

7. Larcher, W. Die Kälteresistenz von Obstbäumen und Ziergehölzen subtropischer Herkunft. Ecol. Plant. 1971, 6, 1-14.

8. Yelenosky, G. Cold Hardiness in Citrus. In Horticultural Reviews; Janick, J., Ed.; John Wiley \& Sons, Inc.: Hoboken, NJ, USA, 1985; pp. 201-238, ISBN 978-1-118-06073-5.

9. Davies, F.S.; Albrigo, L.G. Citrus; CAB INTERNATIONAL: Wallingford, UK, 1994; ISBN 0851988679.

10. Inch, S.; Stover, E.; Driggers, R.; Lee, R.F. Freeze Response of Citrus and Citrus-related Genotypes in a Florida Field Planting. Horts 2014, 49, 1010-1016. [CrossRef]

11. Joublan, J.P.; Cordero, N. Comportamiento de algunos cítricos sobre diferentes portainjertos, en su tercera temporada de crecimiento, Quillón VIII Región, Chile. Agric. Téc. 2002, 62, 469-479. [CrossRef]

12. Yelenosky, G. Accumulation of Free Proline in Citrus Leaves during Cold Hardening of Young Trees in Controlled Temperature Regimes. Plant Physiol. 1979, 64, 425-427. [CrossRef] [PubMed]

13. Thomashow, M.F. Role of Cold-Responsive Genes in Plant Freezing Tolerance. Plant Physiol. 1998, 118, 1-8. [CrossRef] [PubMed]

14. Liu, Y.; Dang, P.; Liu, L.; He, C. Cold acclimation by the CBF-COR pathway in a changing climate: Lessons from Arabidopsis thaliana. Plant Cell Rep. 2019, 38, 511-519. [CrossRef] [PubMed]

15. Yang, T.; Chaudhuri, S.; Yang, L.; Du, L.; Poovaiah, B.W. A calcium/calmodulin-regulated member of the receptor-like kinase family confers cold tolerance in plants. J. Biol. Chem. 2010, 285, 7119-7126. [CrossRef] [PubMed]

16. Zhao, C.; Wang, P.; Si, T.; Hsu, C.-C.; Wang, L.; Zayed, O.; Yu, Z.; Zhu, Y.; Dong, J.; Tao, W.A.; et al. MAP Kinase Cascades Regulate the Cold Response by Modulating ICE1 Protein Stability. Dev. Cell 2017, 43, 618-629.e5. [CrossRef] [PubMed]

17. Chinnusamy, V.; Ohta, M.; Kanrar, S.; Lee, B.; Hong, X.; Agarwal, M.; Zhu, J.-K. ICE1: A regulator of cold-induced transcriptome and freezing tolerance in Arabidopsis. Genes Dev. 2003, 17, 1043-1054. [CrossRef]

18. Ding, Y.; Li, H.; Zhang, X.; Xie, Q.; Gong, Z.; Yang, S. OST1 Kinase Modulates Freezing Tolerance by Enhancing ICE1 Stability in Arabidopsis. Dev. Cell 2015, 32, 278-289. [CrossRef]

19. Ding, Y.; Jia, Y.; Shi, Y.; Zhang, X.; Song, C.; Gong, Z.; Yang, S. OST1-mediated BTF3L phosphorylation positively regulates CBFs during plant cold responses. EMBO J. 2018, 37, e98228. [CrossRef] [PubMed]

20. Miura, K.; Jin, J.B.; Lee, J.; Yoo, C.Y.; Stirm, V.; Miura, T.; Ashworth, E.N.; Bressan, R.A.; Yun, D.-J.; Hasegawa, P.M. SIZ1-Mediated Sumoylation of ICE1 Controls CBF3/DREB1A Expression and Freezing Tolerance in Arabidopsis. Plant Cell 2007, 19, 1403-1414. [CrossRef]

21. Benedict, C.; Skinner, J.S.; Meng, R.; Chang, Y.; Bhalerao, R.; Huner, N.P.A.; Finn, C.E.; Chen, T.H.H.; Hurry, V. The CBF1dependent low temperature signalling pathway, regulon and increase in freeze tolerance are conserved in Populus spp. Plant Cell Environ. 2006, 29, 1259-1272. [CrossRef]

22. Doherty, C.J.; Van Buskirk, H.A.; Myers, S.J.; Thomashow, M.F. Roles for Arabidopsis CAMTA Transcription Factors in ColdRegulated Gene Expression and Freezing Tolerance. Plant Cell 2009, 21, 972-984. [CrossRef]

23. Kidokoro, S.; Yoneda, K.; Takasaki, H.; Takahashi, F.; Shinozaki, K.; Yamaguchi-Shinozaki, K. Different Cold-Signaling Pathways Function in the Responses to Rapid and Gradual Decreases in Temperature. Plant Cell 2017, 29, 760-774. [CrossRef]

24. Kushad, M.M.; Yelenosky, G. Evaluation of Polyamine and Proline Levels during Low Temperature Acclimation of Citrus 1. Plant Physiol. 1987, 84, 692-695. [CrossRef]

25. Vu, J.C.V.; Yelenosky, G. Photosnythetic responses of rough lemon and sour orange to soil flooding, chilling, and short-term temperature fluctuations during growth. Environ. Exp. Bot. 1992, 32, 471-477. [CrossRef]

26. Vu, J.C.V.; Yelenosky, G. Photosynthesis and freeze tolerance comparisons of the newly released "ambersweet" hybrid with "valencia" orange. Environ. Exp. Bot. 1993, 33, 391-395. [CrossRef] 
27. Anwar Hossain, M.; Hoque, M.A.; Burritt, D.J.; Fujita, M. Chapter 16-Proline Protects Plants Against Abiotic Oxidative Stress: Biochemical and Molecular Mechanisms. In Oxidative Damage to Plants; Academic Press: San Diego, CA, USA, 2014; pp. 477-522, ISBN 978-0-12-799963-0.

28. Kaur, G.; Asthir, B. Proline: A key player in plant abiotic stress tolerance. Biol. Plant. 2015, 59, 609-619. [CrossRef]

29. Kishor, P.B.K.; Sangam, S.; Amrutha, R.N.; Laxmi, P.S.; Naidu, K.R.; Rao, K.R.S.S.; Rao, S.; Reddy, K.J.; Theriappan, P.; Sreenivasulu, N. Regulation of proline biosynthesis, degradation, uptake and transport in higher plants: Its implications in plant growth and abiotic stress tolerance. Curr. Sci. 2005, 88, 424-438.

30. Lehmann, S.; Funck, D.; Szabados, L.; Rentsch, D. Proline metabolism and transport in plant development. Amino Acids 2010, 39, 949-962. [CrossRef]

31. Verbruggen, N.; Hermans, C. Proline accumulation in plants: A review. Amino Acids 2008, 35, 753-759. [CrossRef]

32. Verslues, P.E.; Sharma, S. Proline Metabolism and Its Implications for Plant-Environment Interaction. Arab. Book 2010, 8, e0140. [CrossRef]

33. Hare, P.D.; Cress, W.A. Metabolic implications of stress-induced proline accumulation in plants. Plant Growth Regul. 1997, 21, 79-102. [CrossRef]

34. Rentsch, D.; Hirner, B.; Schmelzer, E.; Frommer, W.B. Salt stress-induced proline transporters and salt stress-repressed broad specificity amino acid permeases identified by suppression of a yeast amino acid permease-targeting mutant. Plant Cell 1996, 8, 1437. [CrossRef]

35. Grallath, S.; Weimar, T.; Meyer, A.; Gumy, C.; Suter-Grotemeyer, M.; Neuhaus, J.-M.; Rentsch, D. The AtProT Family. Compatible Solute Transporters with Similar Substrate Specificity But Differential Expression Patterns. Plant Physiol. 2005, 137, 117. [CrossRef] [PubMed]

36. Agüero, J.; del Carmen Vives, M.; Velázquez, K.; Pina, J.A.; Navarro, L.; Moreno, P.; Guerri, J. Effectiveness of gene silencing induced by viral vectors based on Citrus leaf blotch virus is different in Nicotiana benthamiana and citrus plants. Virology 2014, 460-461, 154-164. [CrossRef]

37. Estornell, L.H.; Gómez, M.D.; Pérez-Amador, M.A.; Talón, M.; Tadeo, F.R. Secondary abscission zones: Understanding the molecular mechanisms triggering stylar abscission in citrus. Acta Hortic. 2016, 65-72. [CrossRef]

38. Brunner, A.M.; Yakovlev, I.A.; Strauss, S.H. Validating internal controls for quantitative plant gene expression studies. BMC Plant Biol. 2004, 4, 14. [CrossRef]

39. Pfaffl, M.W. A new mathematical model for relative quantification in real-time RT-PCR. Nucleic Acids Res. 2001, 29, e45. [CrossRef]

40. Hu, C.A.; Delauney, A.J.; Verma, D.P. A bifunctional enzyme (delta 1-pyrroline-5-carboxylate synthetase) catalyzes the first two steps in proline biosynthesis in plants. Proc. Natl. Acad. Sci. USA 1992, 89, 9354-9358. [CrossRef] [PubMed]

41. Ding, Y.; Shi, Y.; Yang, S. Advances and challenges in uncovering cold tolerance regulatory mechanisms in plants. New Phytol. 2019, 222, 1690-1704. [CrossRef]

42. Zhang, Y.; Zheng, S.; Liu, Z.; Wang, L.; Bi, Y. Both HY5 and HYH are necessary regulators for low temperature-induced anthocyanin accumulation in Arabidopsis seedlings. J. Plant Physiol. 2011, 168, 367-374. [CrossRef] [PubMed]

43. Shi, Y.; Ding, Y.; Yang, S. Molecular Regulation of CBF Signaling in Cold Acclimation. Trends Plant Sci. 2018, $23,623-637$. [CrossRef]

44. Chinnusamy, V.; Zhu, J.-K.J.; Zhu, J.-K.J. Cold stress regulation of gene expression in plants. Trends Plant Sci. 2007, 12, 444-451. [CrossRef]

45. Li, H.; Ding, Y.; Shi, Y.; Zhang, X.; Zhang, S.; Gong, Z.; Yang, S. MPK3-and MPK6-Mediated ICE1 Phosphorylation Negatively Regulates ICE1 Stability and Freezing Tolerance in Arabidopsis. Dev. Cell 2017, 43, 630-642.e4. [CrossRef]

46. Dong, C.-H.; Agarwal, M.; Zhang, Y.; Xie, Q.; Zhu, J.-K. The negative regulator of plant cold responses, HOS1, is a RING E3 ligase that mediates the ubiquitination and degradation of ICE1. Proc. Natl. Acad. Sci. USA 2006, 103, 8281-8286. [CrossRef] [PubMed]

47. Ishitani, M.; Xiong, L.; Lee, H.; Stevenson, B.; Zhu, J.-K. HOS1, a Genetic Locus Involved in Cold-Responsive Gene Expression in Arabidopsis. Plant Cell 1998, 10, 1151. [CrossRef]

48. Polisensky, D.H.; Braam, J. Cold-Shock Regulation of the Arabidopsis TCH Genes and the Effects of Modulating Intracellular Calcium Levels. Plant Physiol. 1996, 111, 1271. [CrossRef]

49. Tähtiharju, S.; Sangwan, V.; Monroy, A.F.; Dhindsa, R.S.; Borg, M. The induction of kin genes in cold-acclimating Arabidopsis thaliana. Evidence of a role for calcium. Planta 1997, 203, 442-447. [CrossRef] [PubMed]

50. Whalley, H.J.; Sargeant, A.W.; Steele, J.F.C.; Lacoere, T.; Lamb, R.; Saunders, N.J.; Knight, H.; Knight, M.R. Transcriptomic Analysis Reveals Calcium Regulation of Specific Promoter Motifs in Arabidopsis. Plant Cell 2011, 23, 4079. [CrossRef]

51. Franklin, K.A.; Whitelam, G.C. Light-quality regulation of freezing tolerance in Arabidopsis thaliana. Nat. Genet. 2007, 39, 1410-1413. [CrossRef] [PubMed]

52. Lee, C.-M.; Thomashow, M.F. Photoperiodic regulation of the C-repeat binding factor (CBF) cold acclimation pathway and freezing tolerance in Arabidopsis thaliana. Proc. Natl. Acad. Sci. USA 2012, 109, 15054. [CrossRef] [PubMed]

53. Seo, E.; Lee, H.; Jeon, J.; Park, H.; Kim, J.; Noh, Y.-S.; Lee, I. Crosstalk between cold response and flowering in Arabidopsis is mediated through the flowering-time gene SOC1 and its upstream negative regulator FLC. Plant Cell 2009, 21, $3185-3197$. [CrossRef]

54. Breton, G.; Danyluk, J.; Charron, J.-B.F.; Sarhan, F. Expression profiling and bioinformatic analyses of a novel stress-regulated multispanning transmembrane protein family from cereals and Arabidopsis. Plant Physiol. 2003, 132, 64-74. [CrossRef] 
55. Ruibal, C.; Castro, A.; Fleitas, A.L.; Quezada, J.; Quero, G.; Vidal, S. A Chloroplast COR413 Protein From Physcomitrella patens Is Required for Growth Regulation Under High Light and ABA Responses. Front. Plant Sci. 2020, 11, 845. [CrossRef] [PubMed]

56. Su, C.; Chen, K.; Ding, Q.; Mou, Y.; Yang, R.; Zhao, M.; Ma, B.; Xu, Z.; Ma, Y.; Pan, Y.; et al. Proteomic Analysis of the Function of a Novel Cold-Regulated Multispanning Transmembrane Protein COR413-PM1 in Arabidopsis. Int. J. Mol. Sci. 2018, $19,2572$. [CrossRef]

57. Lundquist, P.K.; Rosar, C.; Bräutigam, A.; Weber, A.P.M. Plastid Signals and the Bundle Sheath: Mesophyll Development in Reticulate Mutants. Mol. Plant 2014, 7, 14-29. [CrossRef]

58. Aggarwal, M.; Sharma, S.; Kaur, N.; Pathania, D.; Bhandhari, K.; Kaushal, N.; Kaur, R.; Singh, K.; Srivastava, A.; Nayyar, H. Exogenous Proline Application Reduces Phytotoxic Effects of Selenium by Minimising Oxidative stress and Improves Growth in Bean (Phaseolus vulgaris L.) Seedlings. Biol. Trace Elem. Res. 2011, 140, 354-367. [CrossRef]

59. Ben Ahmed, C.; Magdich, S.; Ben Rouina, B.; Sensoy, S.; Boukhris, M.; Ben Abdullah, F. Exogenous proline effects on water relations and ions contents in leaves and roots of young olive. Amino Acids 2011, 40, 565-573. [CrossRef]

60. Kamran, M.; Shahbaz, M.; Ashraf, M.; Akram, N.A. Alleviation of drought-induced adverse effects in spring wheat (Triticum aestivum L.) using proline as a pre-sowing seed treatment. Pak. J. Bot. 2009, 41, 621-632.

61. Kaushal, N.; Gupta, K.; Bhandhari, K.; Kumar, S.; Thakur, P.; Nayyar, H. Proline induces heat tolerance in chickpea (Cicer arietinum L.) plants by protecting vital enzymes of carbon and antioxidative metabolism. Physiol. Mol. Biol. Plants 2011, 17, 203. [CrossRef]

62. Khedr, A.H.A.; Abbas, M.A.; Wahid, A.A.A.; Quick, W.P.; Abogadallah, G.M. Proline induces the expression of salt-stressresponsive proteins and may improve the adaptation of Pancratium maritimum L. to salt-stress. J. Exp. Bot. 2003, 54, $2553-2562$. [CrossRef]

63. Zhiming Yan, Z.; Guo, S.; Shu, S.; Sun, J.; Tezuka, T. Effects of proline on photosynthesis, root reactive oxygen species (ROS) metabolism in two melon cultivars (Cucumis melo L.) under NaCl stress. Afr. J. Biotechnol. 2011, 10, 18381-18390. [CrossRef] 